\title{
PHONOLOGICAL CHANGE PROCESSES OF ENGLISH AND INDONESIAN LANGUAGE
}

\author{
1Irma Diani, ${ }^{2}$ Azwandi \\ Universitas Bengkulu, Indonesia1,2 \\ Corresponding email:irmadiani@unib.ac.id
}

\begin{abstract}
Phonological change is a language phenomenon that occurs because language users change the distribution of phonemes in a language. The aims of this study are to explain the phonological processes that occur in English and Indonesian language and to explain the differences in phonological forms between English and Indonesian. The method used in this study is a contrasting-descriptive method by comparing two languages, namely English and Indonesian. The data were taken from the speech of students taking Indonesian and English courses at the University of Bengkulu, totaling 40 students in the first semester. The results show that five types of phonological change processes occurred in English and Indonesian, namely assimilation, metathesis, epenthesis, epithesis, and deletion. The phonological change in English often occurred when two vowel phonemes meet, such as/ea/ shift to /e/, or /i/, phoneme /y/ shift to /i/. Phoneme /e/ was pronounced when two vowel phonemes meet, such as /s/ and /n/ becomes /sen/. Phoneme/g/ is pronounced multiply when it meets the sound/ng/. Phoneme $/ \mathrm{u} /$ is pronounced when it meets phoneme $/ \mathrm{o} /+\mathrm{a}$ consonant. Phoneme $/ \mathrm{h} /$ is unpronounced when it meets a vowel phoneme or more vowel phonemes in the words. Meanwhile, phonological changes in Indonesian often occurred from consonant phonemes to other consonant phonemes that have almost the same sound such as phoneme $/ \mathrm{z} / \mathrm{shift}$ to /s/ and $/ \mathrm{j} /$. Phoneme $/ \mathrm{k} /$ was pronounced after phoneme $/ \mathrm{u} /$ and phoneme $/ \mathrm{h} /$ is pronounced after phoneme $/ \mathrm{a} / \mathrm{at}$ the end of words. Phoneme /y/was pronounced between phonemes /i/ and /a/. Phoneme /h/ was unpronounced when it meets phonemes /a/, /i/, and / $\mathrm{u} /$ in words. In conclusion, the process of phonological change that occurs in English and Indonesian is due to the influence of adjacent phoneme sounds that resemble nearby sounds.
\end{abstract}

Keywords: phonological change processes, English phonological, Indonesian phonological, phonemes 


\section{INTRODUCTION}

In the phonology field, there is a process of phonological change. This phonological change occurs when a speaker pronounces a word in a certain language by changing, adding, inserting, and a sound at the beginning, middle, and end of a word. When two sounds that are close together resemble adjacent sounds in several words, it is called a phonetic process. For example, the word "news" in English / nuz/ or /niuz/ add the word "paper", people pronounce sound / $\mathrm{z} /$ become sound / s / $\rightarrow$ /nuspapor/. The sound changes also occur in other ways, such as voicing into sound, for example, the word north /nor $\Theta /$ ends with a sound / $\Theta /$ but when added with the ending -ern

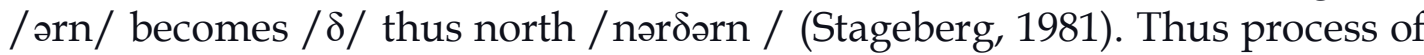
phonological change may occur in Indonesian, English, and other local languages such as Bengkulu Malay.

Phonological changes in pronouncing a word can occur in the form of phonetic changes sounds. Josef (2013) stated that phonetic change is a phonetic implementation of shifting from surface phonological representations. This change will produce a new sound in words. The cases of the phonological change have been a language phenomenon and are often experienced by language learners who study a second language in Indonesia including Indonesian language and English. Abrar et al. (2018) stated that the difficulties that happened by English learners in Indonesia due difference between the phonetic alphabets used in English and Indonesian. Karlina (2020) also argued that the difficulties that happened in Indonesian language are a phonetic language in which there is a direct relationship between spelling and pronunciation. However, students in Indonesia have a variety of language background so that it influences transferring phonological words from their first language to the target language (Zen, 2020). It is in line with the case that happened at the University of Bengkulu in which the students have many regional languages background that affect them in learning and acquiring languages in terms of the phonological process.

A number of researchers have studied phonological processes and phonological changes on several languages. Bouavichit (2014) investigated the effect of Segmental and prosodic on intervocalic voiceless stop reduction in connected speech that conditions the reduction in everyday speech as it affects silent stopping in American English. The study output showed a lack of a clear reduction among the voiceless. Then, Daana (2018) investigated phonological development and phonological process of speech of an EnglishArabic Bilingual Child in Jordan. This study reported that phonological processes such as regressive and progressive assimilation, substitution, and metathesis happened in the child's production of English and Arabic sounds. In addition, in Indonesian context, some scholars have conducted several studies on the phonological process. Those studies are in terms of language 
interference (Diani, 2019), the phonological process in the prefix /me/ (Hardiany, 2019), phonological variations of Serawai and Minangkabau language in the city of Manna, South Bengkulu (Gustina, Nadra, \& Marnita, 2018), and patterns of phonological change in a vowel and consonant phonemes in the absorption of foreign language words into Indonesian (Putriadi, 2016). The results show that there are some additional and deletion of some sounds in words of those languages.

Furthermore, other scholars also have done phonological process investigation in other languages. For example, Behnam and Rassekh-Alqol (2012) investigated metathesis analysis in Azeri language. The metathesis analysis was viewed from age, gender factors, and social class in 120 Azeri speakers in different district of Tabriz, Iran. This study found that men, younger people and lower social class often made metathesis as phonological process in Azeri language. Then, Zee (2015) investigated the phonological process in terms of assimilation process that occurred in Yorkshire language. Zee (2015) distinguished phonetics and phonology based on categorical and gradient. This study found that assimilation that occurred in Yorkshire language involves incomplete sound neutralization that leads to a gradient process. This study also compared the consonant-vowel duration ratios of assimilated items to items assimilated with unvoiced items. The results of the assimilation items differed significantly between voiced and unvoiced.

Based on previous research, studies on phonological processes in both Indonesian and English have not been investigated by scholars maximally. In English, the studies on the phonological process are still limited to assimilation, metathesis, and epenthesis. Meanwhile, other studies only focused on analyzing error pronunciation (e.g. Mulatsih, 2015; Awan et al., 2016; Ganie et al., 2019; Ombat \& Kirigia, 2020), schwa (Mao \& Chen, 2013), and English diphthongs (Donal, 2016). In Bahasa Indonesi, thera are terms of additional prefix, language interferences, phonological variation, phonological change that form in phonemes and consonants. In other words, phonological process is in terms of metathesis and assimilation. There have been no studies focusing on analyzing phonological process and phonological change form between Indonesian and English yet. Therefore, to fill in the gaps in previous research, this present study examined the phonological processes that occur in English and Indonesian. To address the issue, the research questions of this study are as follows:

1. What is the phonological process that occurs in English and Indonesian?

2. How do the phonological change forms differ between English and Indonesian? 


\section{METHODS}

The method used in this study was a contrasting-descriptive method. The descriptive-contrastive method is a method to compare two languages (Yusri, 2018). The two languages mean that the native language of the students' and the target language that the students are studying. Likewise, Misdawati (2019) pointed out that contrastive analysis is a method to find out and explain the language learners' mistakes in learning a language. Thus, this method was chosen to find out and explain the phonological change that occurred in English and Indonesia.

This study involved 40 first semester students who were taking the Indonesian and English course at the University of Bengkulu. It was assumed that first semester students who learned English and Indonesian often changed the phonological of English and Indonesian words. The source of data for this study was the speeches of the students. The speech was public speech, and the students were free to choose the topics based on their interests. The duration of a speech for each student was ten minutes that consisted of 125-150 words in one minute. Thus, the total of words in a speech consisted of 1.250-1.500 words. The observation sheet was used in this study to note the students' speeches during the English and Indonesian teaching and learning process. Then, the data of this study were analyzed with the following procedures;

1. The data (in terms of students' speeches) were grouped into Indonesian and English.

2. The data were identified based on their shape and patterns to see the possible words that had phonological change processes.

3. The possible words that had phonological change were compared to the correct words' pronunciation to see differences.

4. The analysis results were put into the table based on the category of the phonological changes processes.

5. Took the conclusion

\section{FINDINGS}

There were two research questions of this study. The questions are in terms of the phonological change process that occurs in English and Indonesian, and the differences of phonological change forms between English and Indonesian. The results of the analysis are explained in the sub-sections below;

\section{The Phonological Process that Occurs in English and Indonesian}

Based on the results of the analysis data, it was found that the phonological process that occurred in English and Indonesian consisted of five types of 
phonological changes, namely assimilation, metathesis, epenthesis, epithesis, and deletion. They are presented in Table 1.

Table: 1 Assimilation in English and Indonesian

\begin{tabular}{|c|c|c|c|}
\hline \multicolumn{2}{|c|}{ English } & \multicolumn{2}{|c|}{ Indonesian } \\
\hline Basic Form & Change Form & Basic Form & Change Form \\
\hline immoral & inmoral & azaz & asas \\
\hline love you & lopyu & assalam & alsalam \\
\hline hearth & hert & ijazah & ijasah \\
\hline sweat & swit & izin & ijin \\
\hline bear & beer & sabtu & saptu \\
\hline young & yong & & \\
\hline island & islend & & \\
\hline pizza & pija & & \\
\hline mosque & moskyu & & \\
\hline espresso & esprosso & & \\
\hline cheap & chip & & \\
\hline typo & tipo & & \\
\hline
\end{tabular}

Table 1 shows that the phonological changes process that occurred in English and Indonesia was assimilation. It occurred because there is a phoneme changed in a word that is pronounced by the students.

The second type of phonological change process is metathesis. Metathesis is the process of moving sound in a particular word (Stageberg, 1981). The results of the data analysis are presented in Table 2.

Table: 2 Metathesis in English and Indonesian

\begin{tabular}{lccc}
\hline & English & \multicolumn{2}{c}{ Indonesian } \\
\hline Basic Form & Change Form & Basic Form & Change Form \\
\hline tragedy & tradegy & rela & lera \\
relevant & revelant & copot & pocot \\
ask & aks & harap & arap \\
pretty & perty & jilbab & jiblab \\
hundred & hundered & karpet & kapret \\
surrender & sunderer & serbet & sebret \\
mask & maks & peresotan & pesorotan \\
task & taks & tebing & binteng \\
bicycle & bycicle & lidah & dilah \\
& & karton & kraton \\
& & semerbak & semerbak \\
\hline
\end{tabular}

As shown in Table 2, it shows that the changes in the phonological process occurred in terms of segments of words such as syllables. The students 
pronounced the syllables of English and Indonesian words reversely. In the metathesis case, the changes of sounds often occurred in the middle of words.

The third type of phonological change process that occurred in English and Indonesian is epenthesis. The addition of sounds that occurred in the metathesis is by adding a particular sound of phoneme or syllable in a word. The results are presented in Table 3.

Table: 3 Epenthesis in English and Indonesian

\begin{tabular}{llll}
\hline & English & \multicolumn{2}{c}{ Indonesian } \\
\hline Basic Form & Change Form & \multicolumn{1}{c}{ Basic Form } & Change Form \\
\hline something & somepthing & siang & siyang \\
sense & sents & sekalian & sekaliyan \\
snow & senow & biasa & biyasa \\
English & Engglis & biawak & biyawak \\
busy & bussiy & piara & piyara \\
explain & explaein & jumlah & jumblah \\
jungle & jenggel & motor & montor \\
school & sechool & kapak & kampak \\
hoax & hoks & kripik & keripik \\
fried & freied & siskamling & siskambling \\
& & bensin & bengsin \\
\hline
\end{tabular}

As shown in Table 3, the epenthesis occurred in English and Indonesian. It occurred in English and Indonesian by inserting a sound in a word or changing the sound of a phoneme that has almost the same sounds.

The fourth type of phonological change process that occurred in English and Indonesian was Epithesis. This case occurred due to there is an additional sound at the end of the words that were pronounced by students. The results of the data analysis are presented in Table 4.

Table: 4 Epithesis in English and Indonesian

\begin{tabular}{llll}
\hline & English & \multicolumn{2}{c}{ Indonesian } \\
\hline Basic Form & Change Form & \multicolumn{1}{c}{ Basic Form } & Change Form \\
\hline drown & draun & mengapa & mengapah \\
across & acrost & ibu & ibuk \\
whist & wish & ayo & ayok \\
Copy paste & Kopi paste & kenapa & kenapah \\
& & suka & sukak \\
\hline
\end{tabular}

As shown in table 4, it shows that there is an additional phoneme in the English and Indonesian words pronounced by the students. It occurred at the end of the words (Indonesian), and at the beginning of words (English). 
The fifth type of the phonological change process that occurred in English and Indonesia was deletion. The results of the analysis are presented in Table 5.

Table 5. Deletion in English and Indonesian

\begin{tabular}{lccc}
\hline & English & \multicolumn{2}{c}{ Indonesian } \\
\hline Basic Form & Change Form & Basic Form & Change Form \\
\hline shape & sape & sudah & suda \\
house & ouse & tahu & tau \\
high & aig & harap & arap \\
think & tink & arah & ara \\
& & hujan & ujan \\
& menghimbau & mengimbau \\
& susah & susa \\
& kasih & kasi \\
& susah & susa \\
& suruh & suru \\
& letih & leti \\
\hline
\end{tabular}

As shown in table 5, it shows that there is a deletion phoneme in the words pronounced by the students. The deletion of the phoneme occurred in the beginning, middle, and end of the words. In English, the students tended to delete the phoneme at the beginning of the words, while in Indonesian, the students tended to delete the phoneme at the end of the words.

\section{The Differences of Phonological change Forms between English and Indonesian}

Based on the results of the analysis data, it found that different phonological changes form occurred in English and Indonesian consisted of five types of phonological changes, namely assimilation. It can be seen from the changes of phonemes, and it is presented in Table 6.

Table 6. The Differences of Phonological Changes Form between English and Indonesian

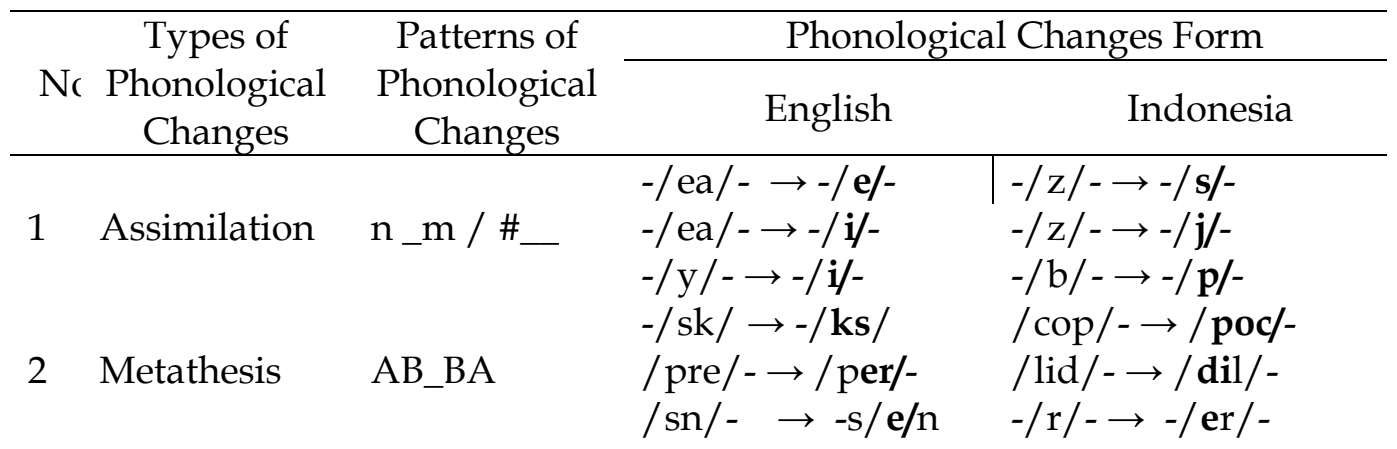




\begin{tabular}{|c|c|c|c|c|}
\hline \multirow[b]{2}{*}{$\mathrm{N}$} & \multirow{2}{*}{$\begin{array}{c}\text { Types of } \\
\text { Phonological } \\
\text { Changes }\end{array}$} & \multirow{2}{*}{$\begin{array}{c}\text { Patterns of } \\
\text { Phonological } \\
\text { Changes }\end{array}$} & \multicolumn{2}{|c|}{ Phonological Changes Form } \\
\hline & & & English & Indonesia \\
\hline 3 & Epenthesis & _ \# _ & $\begin{array}{l}\text {-ie- } \rightarrow-/ \text { e/ie- } \\
-/ \text { ngle }-\rightarrow \text {-ng/g/le } \\
- \\
-/ \text { st } / \rightarrow-\text { s/h/ }\end{array}$ & $\begin{array}{l}-/ \mathrm{ia} /-\rightarrow-\mathrm{i} / \mathrm{y} / \mathrm{a}- \\
-/ \mathrm{en} /-\rightarrow-/ \mathrm{eng} /- \\
-/ \mathrm{ml} /-\rightarrow-\mathrm{m} / \mathrm{b} / \mathrm{l}- \\
-/ \mathrm{a} / \rightarrow-\mathrm{a} / \mathrm{h} /\end{array}$ \\
\hline 4 & Epithesis & & $\begin{array}{l}-/ \mathrm{ss} / \rightarrow-\mathrm{ss} / \mathrm{t} / \\
-/ \text { own } / \rightarrow-/ \mathrm{au} / \mathrm{n}\end{array}$ & $-/ \mathrm{u} / \rightarrow-\mathrm{u} / \mathrm{k} /$ \\
\hline 5 & Deletion & 0 \#_\#_\# & $-/ \mathrm{h} /-\rightarrow-/ 0 /-$ & $/ \mathrm{h} /-\rightarrow / 0 /-$ \\
\hline
\end{tabular}

Notes:

$\mathrm{n} \_\mathrm{m} /$ and \#_ : the change of sounds $\mathrm{n}$ shift to $\mathrm{m}$, and addition of sound at the beginning of words

AB_BA : The change of sounds in form of AB becomes BA in syllables

_ \# _ : : : Addition of sound in the middle of words

- $\quad$ : Addition of words at the end of words

$\mathrm{h}-0$ \#-\#-\# : deletion of sound / $\mathrm{h} /$ in the beginning, middle, and end of words

As presented in Table 6, there are similarities in the changes of patterns in each type of phonological change in English and Indonesian. However, there are differences in the phonological sound changes in each of the phonological patterns of the two languages in terms of phonemes.

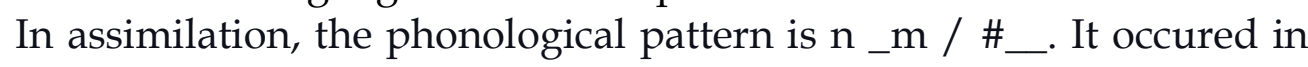
English, namely when two vowel phonemes meet, so the sound of the pronunciation changes into one vowel sound, such as - /ea/ - shift to - /e / $($ heart $\rightarrow$ hert), - /ea/ - shift to - /i/ - (sweat $\rightarrow$ swit), - /y/ - shift to - /i/ (typo $\rightarrow$ ti:po). Whereas in Indonesian, the phonological sound change only occurs in the sound of a consonant phoneme if the consonant phoneme is flanked by the same two vowel phonemes. For example, phoneme - / z/ shift to - /s / - (ijazah $\rightarrow$ ijasah $),-/ \mathrm{z} /$ shift to $-/ \mathrm{j} /$ - (izin $\rightarrow$ ijin $)$, and is enclosed by a vowel phoneme and a consonant phoneme such as - /b/ shift to - /p/ $($ Sa $\underline{b} t u \rightarrow$ Saptu).

In metathesis, the phonological pattern is AB_BA, the phonological changes that occurred in English are the pronunciation of syllable sounds containing vowel and consonant phonemes (/pre/ $\rightarrow /$ per $/-)$, and only two consonants $(-/ \mathrm{sk} / \rightarrow-/ \mathrm{ks} /)$. Whereas in Indonesian, the phonological changes occurred in syllables containing consonant and vowel phonemes only (/lid/ - $\rightarrow$ / dil / -).

In Epenthesis, the phonological pattern is - \# -. It means that there is an insertion or addition of one sound between two specific phonemes. In English case, it occurred by adding phoneme of /e/ between two consonant lines of 
/ $\mathrm{s}+\mathrm{n} /$ (snow $\rightarrow$ senow), adding phoneme of/e/ at the beginning of two vowel phonemes such as - /ie/ - shift to - /e/ (fried $\rightarrow$ freied), and the adding of a consonant phoneme $/ \mathrm{g} /$ after sound of $/ \mathrm{ng} /$ in the middle of a word such (jungle $\rightarrow$ juggle). Whereas in Indonesian, phonological sound changes occur by adding the vowel phoneme /e/ before consonant phoneme /r/ pretty $\rightarrow$ pertty), adding / $/$ / in the middle of two vowel phonemes of /i/ and /a/ (biasa $\rightarrow$ biayasa), adding /g / in sound of / en / - shift to - / eng / - (bensin $\rightarrow$ bengsin), and adding / b/ if the sounds / $\mathrm{m} /$ and /I/ meet (jumlah $\rightarrow$ jumblah).

In epithesis, the phonological pattern is _ \#. In Indonesian, there is an additional phoneme of / $\mathrm{h} /$ after vowel / a/ (apa $\rightarrow$ apah) and consonant of $/ \mathrm{k} /$ after vowel $/ \mathrm{u} /(i b u \rightarrow i b u k)$ in each word that is pronounced by students. This means that sound changes occur in words that end in vowel phonemes only. In English, there tends to be a sound change after the consonant sound at the end of a word by adding the sound $/ \mathrm{h} /$ and $/ \mathrm{t} /$.

In deletion, the phonological pattern is $0 \# \ldots \# \ldots$ \#. The phonological changes occurred in the phoneme $/ \mathrm{h} /$ by eliminating the sounds of the phoneme at the beginning, middle, and end of words in English (house $\rightarrow$ ouse, think $\rightarrow$ tink) and Indonesian (harus $\rightarrow$ arus, susah $\rightarrow$ susa, menghimbau $\rightarrow$ mengimbau).

\section{DISCUSSION}

\section{The Phonological Process that Occurred in English and Indonesian}

Regarding the phonological process that occurred in English and Indonesian, the results show that there were five types of phonological changes, namely assimilation, metathesis, epenthesis, epitasis, and deletion. It indicates that the first semester students of the University of Bengkulu who take English and Indonesian courses still have changes in the pronunciation of the sound of words in Indonesian and in English. The results of this analysis were in line with Bouchhioua's study (2019) who found that the assimilation process that occurred in English words pronounced EFL Tunisian learners often in terms of the same words with this study. The same finding was also found by Daana (2018), phonological process happened in terms of regressive and progressive assimilation, substitution, and metathesis in the child's production of English and Arabic sounds in Jordan. In contrast, Hadi et al. (2003) who reported the phonological process of loanwords from Arabic into Indonesian occurred in many types of process phonological that are categorized into two major groups. They are 1) lenition (e.g reduction of double consonants, aphaeresis, syncope, confession, reinforcement of sounds, loosening of sounds), 2) addition of sounds (e.g. Epenthesis, epithesis, metathesis, monophthongization, assimilation, dissimilation, and vowel splitting). 
Phonological changes that occurred when students pronounced English and Indonesian words were caused by the influence of the language background of the students. As emphasized by Carter and Nunan (2001), Ehrlich and Every (1997), and Donal (2016), differences in language linguistic background, socio-culture, personality, and first language sound system of the language learners affect the production of sounds when they learn the second language or target language. Phonological changes that occur in English and Indonesian also due to the inability of language learners to place sounds according to the sound system of both English and Indonesian appropriately.

Furthermore, the results of the study also show that the phonological changes in the types of metathesis, epenthesis, and deletion. Meanwhile, in English, the students often changed the phonology in the types of assimilation and epithesis. It confirms to Nugraha (2020), the students have difficulties in adapting the phonetic system of their first language into the target language. It is known that the students in this study are mostly Bengkulu people who use various dialects/mother languages such as Bengkulu Malay, Serawai, Rejang, and Lembak which have phonetic differences from Indonesian so when they pronounce an Indonesian word or English, they often change the sound. It confirms to the statement of Karlina et al. (2020) who state that Indonesia has about 700 dialects and not all of the speakers from those are able to speak Bahasa Indonesia fluently. Indonesian speakers still often experience mispronounced the Indonesian words. However, based on this study, the speakers' interlocutors sometimes still understood the meaning of Indonesian words that have phonological change, while sometimes they did not. In English, most interlocutors do not understand the changed words. It is in line with statement of Alteyp (2019) non-native or native speakers of English will not understand the words that have substitution sounds.

\section{The Differences of Phonological change Forms between English and Indonesian}

Regarding the differences in phonological changes form between English and Indonesian, the results of this study show that there are differences in the phonological changes of a phoneme and syllables between Indonesian and English in each type of phonological change process patterns (assimilation, metathesis, epenthesis, epithesis, and deletion). The phonological change in English often occurred when two vowel phonemes meet and one vocal phoneme located between two consonant phonemes, while phonological changes in Indonesian often occurred from consonant phonemes to other consonant phonemes that have almost the same sound. The sounds of words that changed have the uniqueness in both two languages (English and Indonesian) itself when students pronounced them. 
The results of the analysis were in line with Lapoliwa's (2006) study which reported that several phonological changes occurred in Indonesian in terms of degemination of consonants, deletion of trill, deletion phoneme of $/ \mathrm{h} /$, reduction of syllables, naturalization phonemes of $/ \mathrm{z} /, / \mathrm{x} /$, deletion of schwa, nasalization of vowels, insertion of sounds, and sliding of 'glide insertion'. Indrawati (2015) reported that the addition and deletion of sounds at the end of words and the words adopted into Ciacia language, in Buton district, Southeast Sulawesi always have several open syllables. This is because the Ciacia language does not have closed syllables. Then, Gustina (2018) found that there is a correspondence of the sound of a vowel with other vowels that almost have the same sounds (e.g. /e/ with /ə/, /a:/ with /a/, $\mathrm{u} /$ with /o/, and /i/ with /e/. Also, the correspondence of sound between a consonant with other consonants (e.g. /w/ with / $\varnothing /, / b /$ with $[\varnothing]$ and $/ \gamma /$ with /r/, and /W/ with / $\varnothing /$ in Serawai and Minangkabau in the city of Manna, South Bengkulu. The results of this study show that. The last, Rosdiana (2019) investigated the phonological process in the prefix / mem/ in Indonesian. The results of this study reveal that phonologically, there is the addition and assimilation of consonants in the morphophonemic process of Indonesian.

The phonological changes that occurred in English and Indonesia are due to linguistics and non-linguistics factors. Many English words are pronounced differently from the spelling of those words that make many Indonesian language learners are not able to pronounce the English words correctly (Fitriani \& Zulkarnain, 2019). Further, Diani (2016a) postulates that the phonological change occurred due to the occurrence of many language contacts between speakers. They gradually become bilingual or multilingual speakers. This also affects the changes in the phonological pronunciation of words in Indonesian and English when the first semester students of the University of Bengkulu pronounced the words. These changes can be distinguished by seeing and comparing the linguistic elements in one language, which includes differences in phonology, morphology, lexicon, syntax, and semantics (Zulaeha, 2010; Nadra, Reniwati, and Yades, 2006). When it is viewed from the phonetic system of the native language/first language of the students when pronouncing the target language being studied, of course there is also a difference in terms of the number of vowel phonemes and consonants. The most basic thing that affects the sound variation in a language is the vowel sound, which is owned by the language itself. English has twelve vowel sounds, namely /i/, /I/, / e/, / $/$, /æ/, / ə /, / $\Lambda /, / \mathrm{u} /, / v /, / \mathrm{o} /, / \mathrm{o} /$, and /a / (Dardjowidjojo, 2009), while Indonesian has six vowels, namely /a /, /i/, /u/, /e /, /o/, and / / (Aminoedin et al., 1984; Wijana, 2003). There are several similarities in the form of vowel symbols between English and Indonesian (e.g. /i/, /u/, /e /, / o / and / o 
/), but both languages are pronounced with different sounds. It occurred in assimilation process (e.g. /ea/ shift to /e/ or /i/, and /y/ shift to /i:/), metathesis (e.g. / pre/ becomes / per/), epentesisis (e.g. /sn/ becomes /sen /, and / ei / becomes / eie /), epithesis (e.g. / ss / becomes / st /), and deletion (e.g. / h / was unpronounced at the beginning, middle, and end of a word if it meets a phoneme vocals).

The first semester students of the University of Bengkulu in this study have different backgrounds in the mother tongue. Of course, the vowel sounds that exist in their mother tongues also contribute to the process of changing the phoneme sound when pronouncing a word in Indonesian, especially the local language with the largest number of speakers in Bengkulu. For example, Bengkulu Malay has over 41,974 speakers in the city of Bengkulu (Diani, 2016b). Bengkulu Malay language has five vowel phonemes (/i/, /e/ , /a/, /o/ and /u/), the vowel allophones e (E) $(/ \partial /, / E /, / e /)$, and two semivowels (/w/ and /y/) (Supadi, 2015). The semivowel /y/ has a lot of influence on the process of changing the type of epenthesis at the time of pronouncing Indonesian (e.g. biasa becomes biayasa). Rejang language has seven vowel phonemes, namely /i/, /u/, /e/, / $/ /, / \partial /, / \mathrm{o} /$, and /a/ (Wibowo, 2016). Those vowels influence the students in pronouncing the words that contain vowel sounds in English and Indonesian (e.g. assimilation and epithesis).

In addition, the sound of consonant phonemes, which are almost the same sounds in Indonesian, also affects students in pronouncing a phoneme sound. This can be seen in the process of changing the type of assimilation, such as the sound of the phoneme / $\mathrm{z} /$ shift to $/ \mathrm{j} /$ and $/ \mathrm{s} /$. It is in line with the statement of Hadi et al. (2003) who argued that the sound change is caused by the influence of other sounds, namely if a sound causes another sound to change, the two sounds become almost the same or similar to one another.

The findings of this study provide information and insight to lecturers or teachers who teach English and Indonesian about the origin of the phonological changes of a word when speakers speak the words according to the findings of this study. They as language teachers can find the suitable teaching method when teaching how to pronounce the sound of a word in English and Indonesian in Phonetics and Phonology courses at the university level or when teaching English and Indonesian in the classroom at the junior and senior high schools.

\section{CONCLUSION AND SUGGESTION}

As argued in the results section, it can be concluded that the phonological process that occurred in English and Indonesia consisted of five types of changes, namely assimilation, metathesis, epenthesis, epithesis, and deletion. Also, a different phonological change form occurred between English and 
Indonesian. It can be seen from the changes, addition, and deletion of phonemes sound in English and Indonesian words. Phonological changes in Indonesian and English occur due to differences in students' language backgrounds. It is in terms of the phonetic differences in the mother tongue (in this case the regional language) and Indonesian as the lingua franca of Indonesia.

This study also has limitations so that it needs to be studied further and comprehensively. The limitations are in terms of the number of research samples and research objects. Therefore, further researchers are suggested to study the phonological changes in English and Indonesian with more samples to reveal findings that are more comprehensive. Then, further researchers are also suggested to examine errors in pronouncing vowels in English and Indonesian and the linguistic and non-linguistic factors that influence them change.

\section{REFERENCES}

Abrar, M., Mukminin, A., Habibi, A., Asyrafi, F., Makmur, \& Marzulina, L. (2018). "If our English isn't a language, what is it?" Indonesian EFL student teachers' challenges in speaking English. The Qualitative Report, 23(1), 129.

Alteyp, O. A. A. (2019). Interference of phonological aspects of emphatic consonant sounds from Arabic into English consonant sounds for Sudanese University Students of English. International Journal of Applied Linguistics \& English Literature, 8(5), 10-26.

Aminoedin, A., Soedjiatno., Razaq, H. S., Marsoedi, I. L., \& Taryono. (1984). Fonologi bahasa Indonesia: sebuah studi deskriptif. Jakarta: Pusat Pembinaan dan Pengembangan Bahasa.

Awan, A. G., Ayoub, M. T., \& Bashir, B. (2016). Identification of the problems of Saraiki speakers of English in the production of English vowels at secondary level. Journal of Literature, Languages and Linguistics, 6(1), 3544 .

Behnam, B., \& Rassekh-Alqol, B. (2012). A sociolinguistic analysis of metathesis in Azeri Language. International Journal of Applied Linguistics $\mathcal{E}$ English Literature, 1(2), 56-64.

Bouchhioua, N. (2019). Epenthesis in the production of English consonant clusters by Tunisian EFL Learners. Applied Linguistics Research Journal, 3(4), 33-44. doi: 10.14744/alrj.2019.87487.

Bouavichith, D. A. (2014). Segmental and prosodic effects on intervocalic voiceless stop reduction in connected speech. The Journal of the Acoustical Society of America, 135(4), 2294-2294.

Carter, R., \& Nunan, D. (2011). The Cambridge guide to teaching English to speakers of Other languages. Cambridge: Cambridge University Press. 
Daana, H. A. (2018). Phonological development and phonological processes in the speech of an English-Arabic bilingual child. International Journal of Applied Linguistics E English Literature, 7(5), 197-206.

Dardjowidjoyo, S. (2009). English phonetics and phonology for Indonesian. Jakarta: Yayasan Obor Indonesia.

Diani, I. (2019). Interferensi bahasa Indonesia terhadap kemampuan berbicara Bahasa Inggris mahasiswa Universitas Bengkulu. Bengkulu: Universitas Bengkulu.

Diani, I. (2016a). Berbagai faktor penyebab pergeseran penggunaan bahasa Serawai. Daun Lontar, 3(3), 14-35.

Diani, I. (2016). Language shifting of Serawai. Yogyakarta: Universitas Gadjah Mada.

Donal, A. (2016). Indonesian students' difficulties in pronouncing English diphthongs. Journal of English Education, 2(2), 55-62.

Ehrlich, S., \& Every, P. (1997). Gender as social practice: implications for second language acquisition. In Studies in Second Language Acquisition. England: Cambridge University Press.

Fitriani, N., \& Zulkarnain, S. I. (2019). Vocational college students' common errors in EFL speaking performance. Studies in English Language and Education, 6(1), 141-151.

Ganie, R., Wahyu Maulana, W., \& Rangkuti, R. (2019). Errors in pronouncing English phonemes: A praat analysis. Language Literacy: Journal of Linguistics, Literature and Language Teaching, 3(1), 49-63.

Gustina, L., Nadra, N., \& Marnita, R. (2018). Phonological variation in Serawai language that used by Minangkabaunese and Serawainese in kota Manna, South Bengkulu. Jurnal Arbitrer, 5(1), 8-16.

Gustina, N. M. (2018). Phonological Variation in Serawai Language that used by Minangkabaunese and Serawainese in Kota Manna, South Bengkulu. Jurnal Arbitrer, 8-16.

Hadi, S., Chamamah, S., Ramlan, M., \& Wijana, I. D. P. (2003). Perubahan fonologis kata-kata serapan dari bahasa Arab dalam bahasa Indonesia. Humaniora, 15(2), 121-132.

Hardiany, D. R. (2019). proses Foologis Pada Prefiks /me-/ dalam Bahasa Indonesia. Philosophica Vol II No1 Juni, 33.

Indrawati, D. (2015). Proses fonologis dalam pengadopsian tata Bahasa Indonesia ke dalam Bahasa Ciacia di Kabupaten Buton, Sulawesi Tenggara. Jurnal Pena Indonesia: Jurnal Bahasa Indonesia, Sastra dan Pengajaran, 1(1), 97-104.

Josef, F. (2013). Dissertation: the phonological influence on phonetic change. Manchester: University of Manchester.

Karlina, Y., Rahman, A., \& Chowdhury, R. (2020). Designing Phonetic Alphabet for Bahasa Indonesia (PABI) for the teaching of intelligible 
Phonological Change Processes of English and Indonesian Language

English pronunciation in Indonesia. Indonesian Journal of Applied Linguistics, 9(3), 724-732.

Lapoliwa, H. (2006). A Generative Approach to the phonology of Bahasa Indonesia.

Canberra: Pacific Linguistics Series D No 34. Retrieved from https://openresearchrepository.anu.edu.au/bitstream/1885/145047/ 1/PL-D34.pdf.

Mao, H., \& Chen, H. (2013). Exploring elision of Schwa of /ə/ in English utterances by C \& U English majors. International Journal of Applied Linguistics \& English Literature, 2(1), 117-125.

Misdawati. (2019). Analisis kontrastif dalam pembelajaran bahasa. 'Ajamiy: Jurnal Bahasa dan Sastra Arab, 8(1), 53-66.

Mulatsih, D. (2015). Pronunciation ability by using English song in Indonesian students of University of Unswagati Cirebon. Journal of English Language and Learning, 2(2), 294-299.

Nadra, N., Reniwati, R., \& Yades, E. (2006). Seminar Pembahasan Hasil Penelitian RUKK VI, Kementerian Negara Riset dan Teknologi, Jakarta.

Nugraha, Z. A. (2020). Kesalahan pelafalan fonem bahasa Indonesia oleh pemelajar asal Tiongkok. Batra, 6(1), 23-34.

Ombati, J. N., \& Kirigia, E. K. (2020). L2 English pronunciation errors by Kenyan university students: A case of L1 Ekegusii and L1 Kimeru speakers. International Journal of Linguistics, Literature and Translation (IJLLT), 3(8), 197-20.

Putriadi, A. W. (2016). Pola-pola perubahan fonem vokal dan konsonan dalam penyerapan kata-kata bahasa asing ke dalam Bahasa Indonesia: kajian fonologi. Jurnal Arbitrer,3(2), 96-112.

Rosdiana, D. R. (2019). Proses Fonologis pada Prefiks /me-/ dalam Bahasa Indonesia. Jurnal Philosophica,2(1) ,33-40.

Stageberg, N. (1981). An introductory English grammar. United States of America: Holt, Rinehart and Winston.

Supadi. (2015). Penyusunan tata bahasa Melayu Bengkulu. Diksa, 1(2), 10-117.

Wibowo, S. F. (2016). Fonem segmental dan distribusinya dalam Bahasa Rejang dialek Musi. Mada, 7(1), 37-46.

Wijana, I. D. P. (2003). Indonesian vowel and their allophone. Humaniora, 15, (1), 39-42.

Yusri, M. R. (2018). Analisis kontrastif pembentukan komposita nomina (Verba+Nomina) dalam Bahasa Jerman dan Bahasa Indonesia. Procceding of Kolita 16 (p. 309), Jakarta: Pusat Kajian Bahasa dan Budaya Universitas Katolik Indonesia Atmajaya.

Zee, T. (2015). Yorkshire Assimilation, An experimental Investigation of Gradient Phonological Alternation. Utrecht: Utrecht University.

Zen, E. L. (2020). Role of regional language background and speech styles on the production of Voice Onset Time (VOT) in English among 
Irma Diani; Azwandi

Indonesian multilingualism. Indonesian Journal of Applied Linguistics, 10(2), 359-368.

Zulaeha, I. (2010). Dialektologi: dialek geografi dan dialek sosial. Yohyakarta: Graha Ilmu. 